\title{
IZAZOVI I MOGUĆNOSTI POPULARIZACIJE LOKALNE POVIJESTI - PRIMJER RANONOVOVJEKOVNE VOJNOKRAJIŠKE I SENJSKE POVIJESTI
}

Karlo Rukavina

Frankopanski trg 2

UDK: 94(497.5Senj)"16"

HR 53270 Senj

Stručni članak

karlo.rukavina97@gmail.com

Ur.: 2021-07-01

Filip Šimunjak

Ante Mike Tripala 1

HR 10090 Zagreb

filipsimunjak@gmail.com

U današnjem digitalnom svijetu, obilježenom globalizacijom i brzim prijenosom informacija na izvanredne udaljenosti, društveni i javni položaj historiografije - koja se našla u novim uvjetima bez presedana - dovedeni su u pitanje, posebno kada je riječ o izazovima popularizacije povijesti. Unutar niza pitanja koja popularizacija povijesti otvara, moguće je izdvojiti manju cjelinu koja nas ovdje zanima - lokalnu povijesti i njezinu prezentaciju. U ovom radu predstavit će se izazovi i mogućnosti popularizacije znanstveno utemeljenih spoznaja historiografije na primjeru senjske povijesti i projekta Bulwark of Europe. krajina

Ključne riječi: javna povijest, popularizacija povijesti, Senj, Nehaj, uskoci, Vojna

\section{Uvod}

Spoznaje o povijesti danas se ne posreduju samo znanstvenim radovima i stručnom literaturom uže akademske zajednice profesionalnih i visoko obrazovanih povjesničara. Povijest je neizbježan dio svakodnevnog života, medijskih članaka i rasprava, filmova, pjesama, romana, videoigara te turizma zbog čega se može zaključiti kako popularizacija povijesti u javnoj sferi oblikuje našu sadašnjost. ${ }^{1}$ Javna povijest (eng. public history) znanstvena je disciplina

\footnotetext{
${ }^{1}$ H. KEAN, 2018, 44.
} 
koja se bavi navedenim pitanjima istraživanja uloge povijesti i povjesničara u današnjem društvu te popularizacije povijesti. Iako mnogi smatraju da je riječ o jednoj od historiografskih subdisciplina, možda bi bilo bolje govoriti o interdisciplinarnom području koje spaja elemente historiografije, arheologije, etnologije i drugih srodnih društveno-humanističkih znanosti s tehnologijom, turizmom, književnošću i umjetnošću te ovaj amalgam spoznaja i pristupa razmatra unutar šireg društveno-kulturnog konteksta, a potom plasira nove spoznaje u javnost. ${ }^{2}$

Lokalnu povijest - povijest određenog lokaliteta poput sela ili grada također bitno određuje način na koji se povijest popularizira. Popularizacijom se naglašavaju odabrani segmenti lokalne povijesti te ih se integrira u nacionalne i nadnacionalne društvene okvire. Sličan proces može se pratiti i na primjeru popularizacije senjske povijesti - zbirke Gradskog muzeja Senj, muzejski postav u utvrdi Nehaj, turistička manifestacija Uskočki dani i film Doba uskoka samo su neki primjeri približavanja bogate senjske povijesti široj javnosti. Projekt Bulwark of Europe - Digitizing the Habsburg-Ottoman Frontier također se svrstava u navedenu skupinu primjera popularizacije senjske povijesti, a u konkretnom slučaju riječ je o popularizaciji i prezentaciji uloge Senja u kontekstu Vojne krajine u 16. stoljeću.

Prije predstavljanja popularizacijskih aktivnosti, ukratko će se predstaviti projekt Bulwark of Europe. U radu će se zatim odgovoriti na nekoliko istraživačkih pitanja: Koja je važnost Senja za projekt Bulwark of Europe, tj. u kontekstu Vojne krajine? Kako navedeni projekt popularizira senjsku povijest? Kako se internet i društvene mreže mogu iskoristiti za popularizaciju senjske povijesti? Koji su prednosti i nedostatci popularizacije senjske povijesti na primjeru projekta Bulwark of Europe?

\section{O projektu i važnosti Senja u kontekstu Vojne krajine}

Bulwark of Europe projekt je koji se primarno bavi proučavanjem rane faze Hrvatske i Slavonske vojne krajine, tj. razdobljem od sredine 16. stoljeća do "konsolidacije" Krajine na Saboru u Brucku na Muri 1578. godine, iako se aktivnošću na društvenim mrežama dotiče sveobuhvatnog razdoblja kontakata Europljana s Osmanskim Carstvom (od 15. do 19. stoljeća). Cilj projekta je približiti Vojnu krajinu široj publici na zanimljiv i interaktivan način.

${ }^{2}$ R. CONARD, 2018, 19; D. DEAN, 2018, 1-6. 


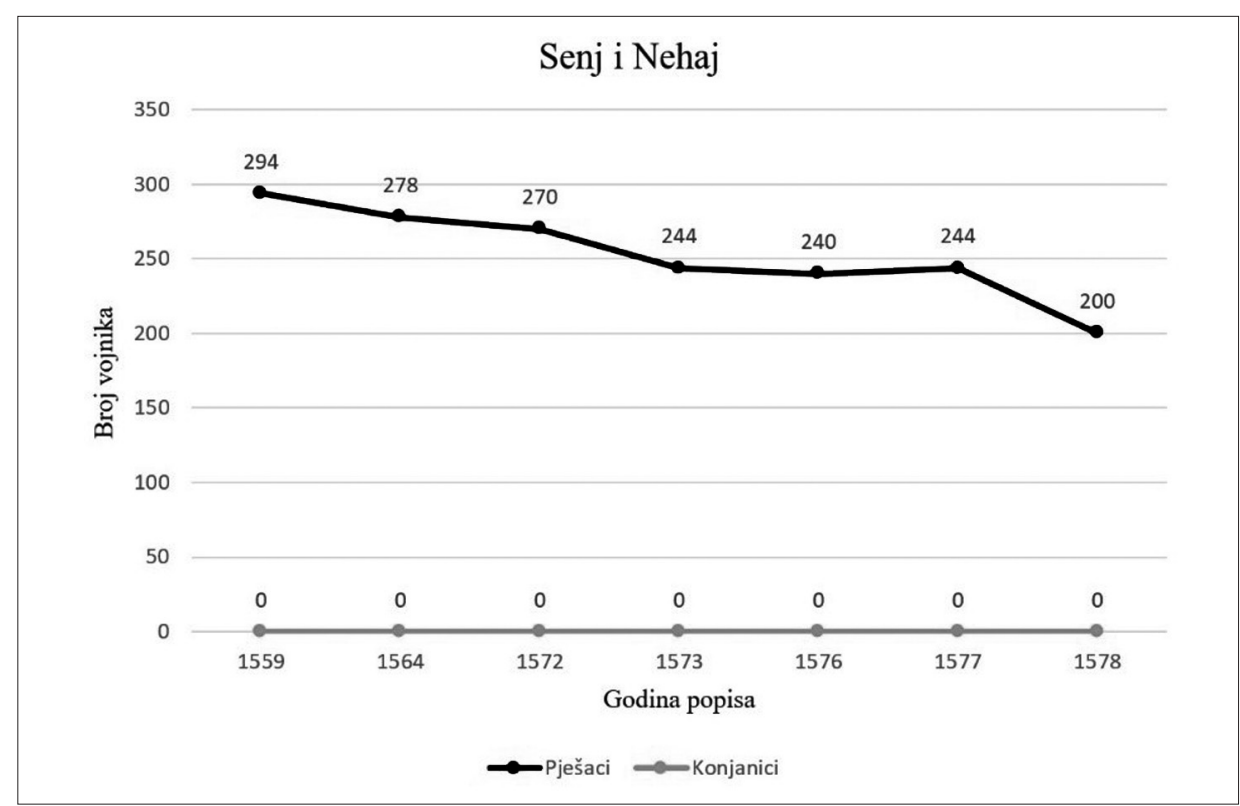

Sl. 1. Grafički prikaz kretanja broja krajiških postrojbi u Senju i Nehaju (izradili: K. Rukavina i F. Šimunjak)

Projekt je započeo u sklopu kolegija "Uvod u istraživački rad" nositeljice prof. dr. sc. Nataše Štefanec, na kojemu je grupa studenata transkribirala i obradila zasad najraniji poznati krajiški popis (Kriegsstaat) iz 1556. godine, pisan njemačkom goticom. ${ }^{3}$ Projekt naglašava važnost javnog djelovanja (tj. javnu povijest) povjesničara te prezentacije historiografskih spoznaja publici na jednostavan $\mathrm{i}$ interaktivan način digitalnim putem, tj. koristeći alate tzv. digitalne humanistike. ${ }^{4}$ Prije svega, projekt koristi interaktivne karte na kojima se u svega nekoliko klikova računalnog miša može doći do informacija koliko se vojnika nalazilo u pojedinoj krajiškoj utvrdi odabrane godine. Primjerice, za Senj i Nehaj sačuvani su podatci za 1559., 1564., 1572., 1573., 1576., 1577. i 1578. godinu.

Iako se Senj - kao dio Hrvatske (i Primorske) vojne krajine - ne spominje u popisu iz 1556. godine (od kojega je projekt krenuo), zapravo je

${ }^{3}$ Transkript je naknadno objavljen zajedno s uvodnom studijom, popratnim tablicama i kartama. Vidi: P. HEGEDIĆ et al., 2019, 345-375.

${ }^{4}$ Više o samom projektu vidi u: M. JURKOVIĆ - F. ŠIMUNJAK, 2020, 32-33; F. ŠIMUNJAK, 2021, 65-67 te na mrežnoj stranici projekta (https://vojnakrajina.ffzg.unizg.hr/onama). 
riječ o krajiškom središtu koje je projekt, zbog njegove iznimne vojne važnosti, obradio među prvima. Naime, osim što je Senj činio jednu od ključnih točaka obrane Ugarskog Kraljevstva još u vrijeme prvih obrambenih reformi kralja Matije Korvina ${ }^{5}$, upravo je u Senju osnovana prva kapetanija na prostoru Hrvatske (1469. godine), nakon što je on - zajedno s Otočcem i Brinjem oduzet Frankopanima. Razlog oduzimanja bio je, među ostalim, i približavanje frankopanskog kneza Stjepana II. austrijskom vladaru i mletačkom duždu zbog čega je ugarski vladar bio zabrinut oko eventualnog širenja utjecaja susjednih sila na prostor Senja. ${ }^{6}$ No, izgleda da su ti rani sustavi obrambenih linija i kapetanija iz vremena hrvatsko-ugarskih kraljeva Sigismunda i Korvina propali do 1520-ih/1530-ih godina te su kapetanije 16. stoljeća rezultat ponovne organizacije sustava, a ne njegova kontinuiteta. ${ }^{7} \mathrm{Za}$ to je prije svega bio zaslužan Ivan Lenković. Godine 1559. nema jasne kapetanijske podjele na Hrvatskoj krajini već se navodi samo "stara Hrvatska krajina od Bihaća do mora i nova Hrvatska krajina od Siska do Bihaća". No, već na sljedećem popisu koji nam je sačuvan, iz 1564. godine, pojavljuje se jasan kapetanijski ustroj - dvije "stare oživjele" kapetanije (Senjska i Bihaćka) te dvije "potpuno nove" - Ogulinska i Hrastovička kapetanija. ${ }^{8}$ Prema tome možemo zaključiti da je (re)organizacija sustava kapetanija na Hrvatskoj krajini provedena negdje između 1559. i 1564. godine.

Senj je u kontekstu Vojne krajine također posebno važan kao središte (polu)profesionalne vojske - tj. uskoka - koji su s prostora Senja i Klisa imali zadatak braniti pozadinu od provala Osmanlija, vršiti prodore i upade na

${ }^{5}$ Reformama kralja Matije (Matijaša) Korvina između 1464. i 1476. godine formiran je sustav obrane Ugarskog Kraljevstva u dvije linije utvrda - Szörény, Orsova, Szentlászló, Beograd, Zemun, Šabac, Srebernik, Jajce, Knin, Skradin i Klis (južnija linija) te Lugos, Karánsebes, Temišvar, Petrovaradin, manje utvrde Srijema, Dubica, Krupa, Bihać i Senj (sjevernija linija); G. PÁLFFY, 2000, 12; I. JURKOVIĆ, 2019, 119-120.

${ }^{6}$ N. MOAČANIN, 2016, 141; K. KASER, 1997, 48; J. KURELIĆ, 2019, 556.

${ }^{7}$ N. ŠTEFANEC, 2011, 397-398; D. STANIĆ, 2020, 35-48.; Za obrambenu strukturu iz vremena Sigismunda i Korvina vidi recentni rad Ivana Jurkovića (I. JURKOVIĆ, 2019, 115-135) te niz radova iz zbornika J. BAK - B. KIRÁLY, 1982, posebno F. SZAKÁLY, 1982, 141-158 (također od istog autora vidi: F. SZAKÁLY, 1979, 65-111); A. KUBINYI, 2000, 71-115. Pitanjem Senjske kapetanije nedavno se u doktorskoj disertaciji bavio Vedran Klaužer (usp. V. KLAUŽER, 2015) koji nastoji prikazati da je kapetanija od osnivanja 1469. godine cijelo vrijeme bila u funkciji, tj. da "cjelokupni prikaz stanja od 1469. do 1563. godine pokazao je da su vladari na mjesto senjskih kapetana postavljali izuzetno sposobne i povjerljive osobe koje su znale čuvati ovaj izdvojen kraljevski prostor na području Kraljevine Hrvatske te voditi kompleksnu upravu ove vojno-teritorijalne jedinice" (207).

${ }^{8}$ N. ŠTEFANEC, 2011, 398, 475-477. 


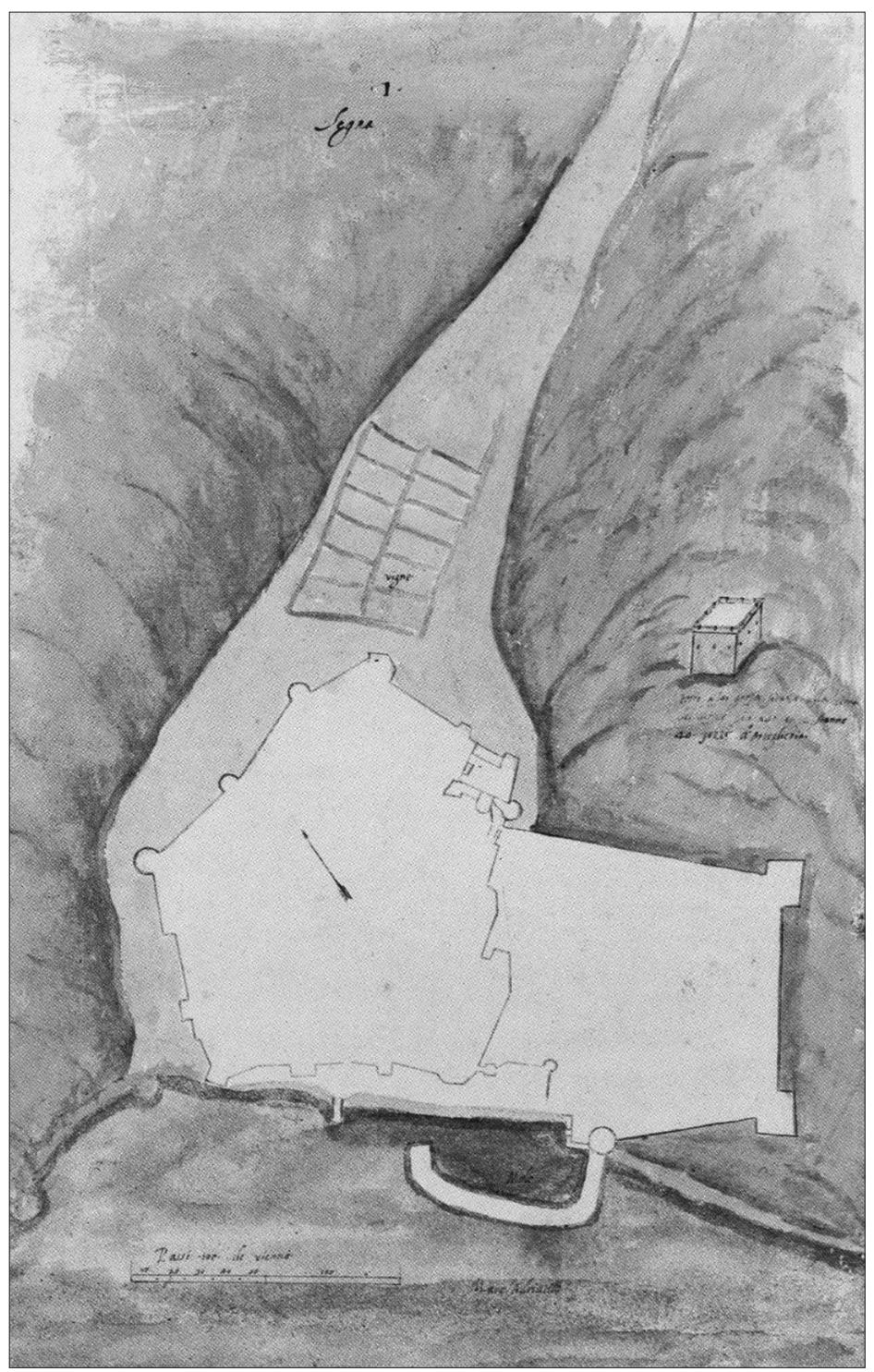

Sl. 2. Idejni prikaz Senja i Nehaja Nicole Angielinija iz 1566. godine ${ }^{9}$ (Sächsisches Hauptstaatsarchiv, Dresden, Sch. XXVI, F. 96, N. 11) (izvor: LJ. KRMPOTIĆ, 1997, 212)

${ }^{9}$ Angielini je na svojem prikazu, osim jezgre Senja, prikazao i idejni plan proširenje i dodatne fortifikacije Senja bastionskom utvrdom koja - dakako - nikad nije realizirana. 


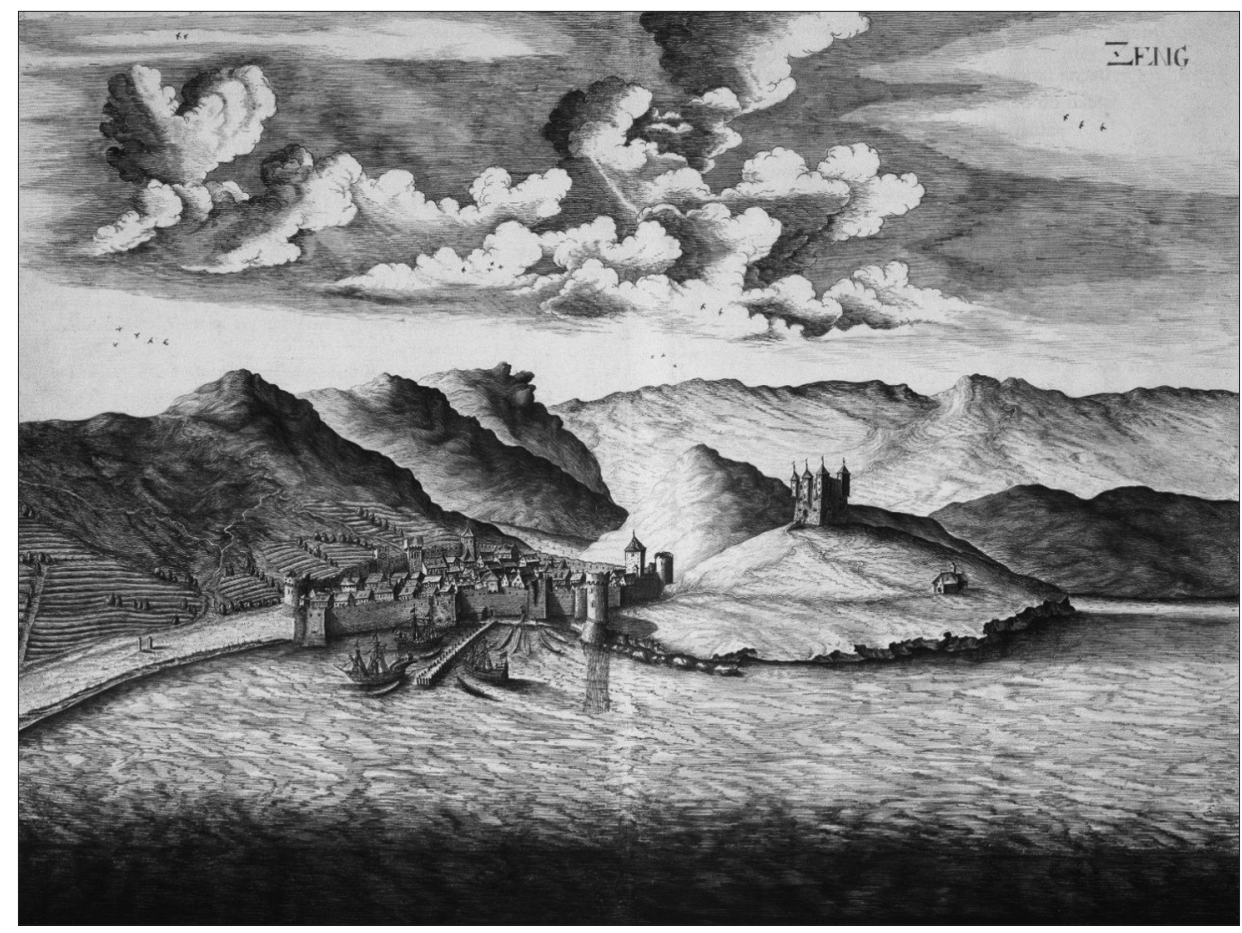

Sl. 3. Prikaz Senja i Nehaja Martina Stiera iz 1657. godine (Österreichische Nationalbibliothek, Beč, Cod.8608, fol. 102) (izvor: LJ. KRMPOTIĆ, 1997, 125)

osmanski prostor, ali i napadati Mlečane. ${ }^{10}$ Uskoci su u Senju prisutni već od prvih desetljeća 16. stoljeća, no čini se kako se naziv "uskok" kao opći naziv za osobe koje vrše upade na neprijateljski teritorij počeo etablirati krajem 1550-ih i početkom 1560-ih. ${ }^{11}$ Na popisima 1570-ih godina spominje se oko 200 plaćenih uskoka u samom gradu Senju, a računa se da ih je ukupno bilo između $1000 \mathrm{i}$ 2000 u okolici grada. ${ }^{12}$

Za razvoj obrane Hrvatskog Kraljevstva posebno je važan događaj bio dogovor o suradnji kralja Ferdinanda i staleža Unutarnje Austrije kojim je

${ }^{10}$ I. JURKOVIĆ, 2019, 128.

${ }^{11}$ C.W. BRACEWELL, 1997, 59. Posebno su vrijedni izvori sačuvani krajiški popisi iz 1540. godine za Hrvatsku krajinu u Senju i Otočcu (R. LOPAŠIĆ, 1889, 392-395) te popis tzv. Primorske krajine iz 1551. godine (406-411). Oba izvora dostupna su na mrežnoj stranici projekta: https:// vojnakrajina.ffzg.unizg.hr/krajiski-popisi/.

${ }^{12}$ S. LAZANIN - N. ŠTEFANEC, 2000, 98. Općenito o podrijetlu i brojnosti uskoka vidi u: C.W. BRACEWELL, 1997, 53-63. 
utvrđeno da će se na Hrvatsko-slavonskoj krajini uzdržavati stalna plaćenička vojska pod zapovjedništvom jednog zapovjednika. Na tu je dužnost imenovan Ivan Lenković koji je također bio i zapovjednik Hrvatsko-slavonske vojne krajine. U njegovo vrijeme, 1558. godine, podignut će se utvrda Nehaj iznad Senja kao važna točka obrane. ${ }^{13}$ Podizanje Nehaja Lenković je zagovarao još 1550 . godine u svojem izvještaju o stanju Primorske krajine, u kojem ujedno sugerira i potrebne dorade za utvrđivanje Senja: "nakon izvedbe svih tih predloženih utvrđivanja i poboljšanja ovog mjesta, što se savjetuje odmah započeti, jer je grad sa jedne [jugo-istočne] strane sa prilično širokim brdom znatno nadvišen, pa kad ga dakle neprijatelj u svoju korist zauzme i na njemu se utabori, bilo bi premalo mjesta na gradskim zidovima na kojima bi ratnik mogao imati zaštićeni obrambeni položaj, jer na brdu ne postoji nikakav jaki [obrambeni] toranj ili utvrda sa koje bi se moglo obraniti ne samo [to] brdo nego i čitav grad sa morskom lukom i dolinama \{u kojima bi se neprijatelj također utaborio). Dok se takova tvrđava ne podigne, sve su te upravo navedene utvrde pred nekom silom uzaludne. Ako Kralj. Vel. želi očuvati ovo mjesto pred nekom neprijateljskom silom onda je nezaobilazna izgradnja jakog tornja sa cisternom."14

\section{Od lokalne povijesti do društvenih mreža}

Lokalna povijest često je zanimljiva samo užoj akademskoj zajednici profesionalnih povjesničara te samoj lokalnoj zajednici. Treba pritom naglasiti kako je ponekad vrlo teško zainteresirati i lokalno stanovništvo za povijest određenog mjesta (osim nekoliko poznatih epizoda lokalne povijesti), zbog čega se postavlja pitanje kako popularizirati lokalnu povijest i zaintrigirati šire stanovništvo za istu? Vjerojatno je najbolji odgovor na navedeno pitanje upravo kontekstualizacija lokalne povijesti unutar nacionalnih i nadnacionalnih povijesnih okvira. ${ }^{15} \mathrm{U}$ sklopu projekta Bulwark of Europe kontekstualizacija senjske povijesti naglašava važne vojne, političke i urbano-arhitektonske segmente iz povijesti Senja i Nehaja u kontekstu Vojne krajine 16. stoljeća, ali i povijest svakodnevice. Uz to, sve se spoznaje prezentiraju i na engleskom jeziku. Tako projekt lokalnu senjsku povijest popularizira široj hrvatskoj, ali i svjetskoj publici. Projekt se bavi popularizacijom povijesti pomoću digitalne

13 Ž. HOLJEVAC - N. MOAČANIN, 2007, 13. Više o utvrdi Nehaj, tipizaciji i povodu gradnji vidi u: K. RUKAVINA, 2021. Ivan Lenković obnašat će tu funkcije sve do 1567. godine.

${ }^{14}$ LJ. KRMPOTIĆ, 1997, 232-233. Cijeli izvještaj dostupan je na mrežnoj stranici projekta: https://vojnakrajina.ffzg.unizg.hr/utvrde-i-obrana-u-izvjestaju-ivana-lenkovica-iz-1550-godine/.

${ }^{15}$ W. G. CLARKE - J. K. LEE, 2004, 84. 
humanistike zbog čega se velika pažnja posvećuje upravo mrežnoj i Facebook stranici projekta, tj. društvenim mrežama.

Na mrežnoj stranici projekta dosad su objavljena dva eseja važna za popularizaciju senjske povijesti. Prvi se bavi utvrdama Senja u ranome novom vijeku (gradske zidine, kule i gradski kaštel) ${ }^{16}$, a drugi utvrdom Nehaj kao primjerom prijelaznog tipa utvrde $\mathrm{s}$ fortifikacijskim karakteristikama srednjovjekovnih i ranonovovjekovnih utvrda na hrvatskom povijesnom prostoru. ${ }^{17}$ Osim opisa navedenih fortifikacija, uz svaki esej nalazi se i 3D rekonstrukcija utvrda. Naime, smatramo kako upravo 3D modeli najbolje približavaju utvrde široj javnosti, ali i burgologiju kao historijsko-arheološku disciplinu. ${ }^{18}$ Vizualna i interaktivna prezentacija znanstvenih podataka o senjskoj povijesti privlačna je današnjoj, osobito mlađoj publici o čemu svjedoči i sve veće korištenje e-nastave i e-pomagala u obrazovnom sustavu. Kao budući profesionalni povjesničari nadamo se da će stranica svojim sadržajima privlačiti sve više nastavnika i profesora te služiti u pedagoško-didaktičke svrhe. Uz eseje, na stranici se nalaze i izvorni povijesni prikazi Senja i Nehaja; u slučaju Senja riječ je o prikazu Nicole Angielinija iz 1566. godine, dok je esej o Nehaju osim Angelinijevim prikazom - popraćen i bakrorezom J. W. Valvasora iz 1689. godine, prikazom Nehaja Giovannija Pieronija te prikazom Martina Stiera iz 1657. godine. ${ }^{19}$ Pored eseja treba spomenuti kako su na mrežnoj stranici projekta Senj i Nehaj prikazani u kontekstu Vojne krajine i na interaktivnim kartama. Karte osiguravaju podatke o brojčanom stanju krajiške posade u utvrdama te o ulozi Senja u kontekstu razvoja vojnokrajiške pošte na hrvatskom povijesnom

\footnotetext{
${ }^{16}$ Više o utvrdama Senja vidi na mrežnoj stranici projekta: https://vojnakrajina.ffzg.unizg. hr/grad-senj/.

${ }^{17}$ Više o utvrdi Nehaj vidi na mrežnoj stranici projekta: https://vojnakrajina.ffzg.unizg.hr/ nehaj-3/.

18 Prije desetak godina uopće nije postojala znanstvena disciplina koja bi se bavila tipizacijom utvrda i njihovom analizom s obzirom na mjesto gradnje, volumenske osobine, namjenu i druge slične čimbenike i karakteristike koje bi pojedine utvrde mogle tipizirati uz pomoć povijesti, arheologije, povijesti umjetnosti te drugih znanosti i znanstvenih disciplina. Međutim, Zorislav Horvat, diplomirani arhitekt, u svome djelu Burgologija - Srednjovjekovni utvrđeni gradovi kontinentalne Hrvatske predstavlja metodologiju pomoću koje analizira prije svega srednjovjekovne utvrde, to jest burgove i njihove glavne elemente utvrđenja. Njegovo djelo i metodološki pristup imao je uzor u metodama i pristupima prije svega njemačke i britanske historiografije, arheologije, povijesti umjetnosti i drugih znanosti koje su dale doprinos analizi fortifikacijskih elemenata njemačkih i britanskih utvrda kroz povijest. Više o burgologiji vidi u: Z. HORVAT, 2014.

${ }^{19}$ Više o prikazima Nehaja vidi u: A. ŽMEGAČ, 2002, 19-29; 2004, 5-14.
} 


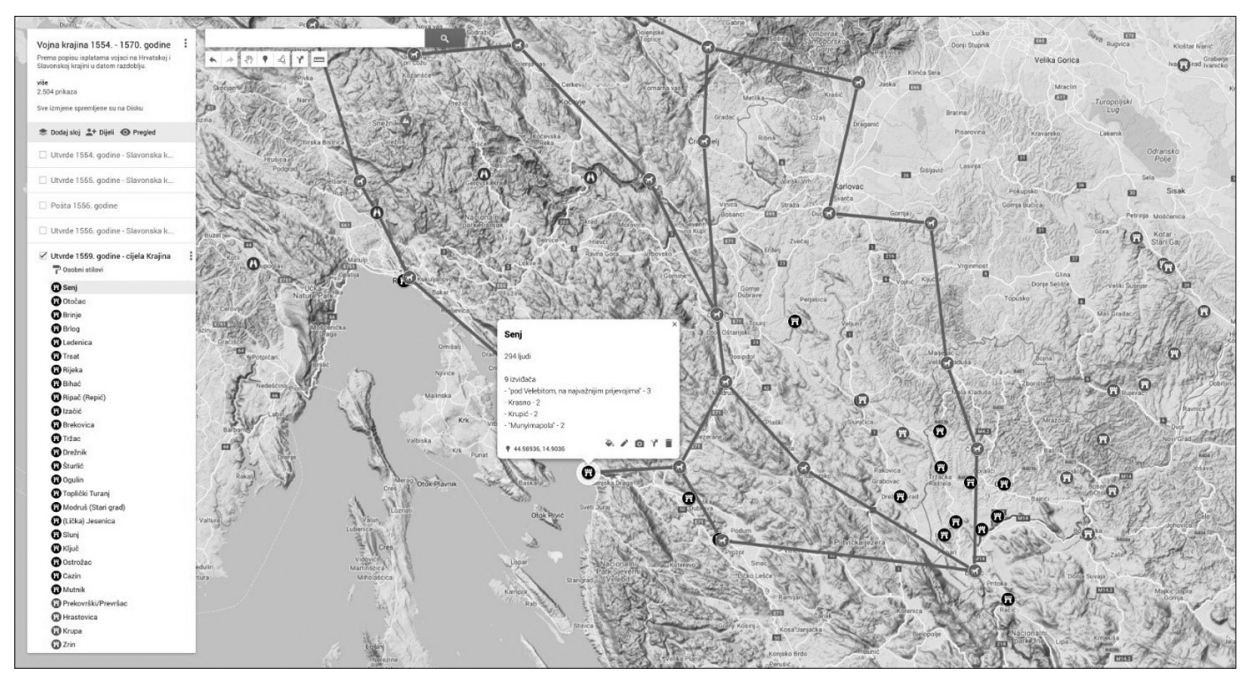

Sl. 4. Broj krajiških vojnika u Senju na popisu iz 1559. godine (digitalna karta) (autor: Filip Šimunjak)

prostoru, pa se tako daje informacije o broju poštarskih konja ili poštara pješaka koji su bili stacionirani u Senju.

Projekt Bulwark of Europe, osim mrežne stranice, za popularizaciju Vojne krajine koristi i društvene medije, a ponajviše Facebook stranicu na kojoj se redovito objavljuju zanimljive epizode iz ranonovovjekovne hrvatske povijesti. U nešto više od godinu dana postojanja stranica je prikupila preko 3500 pratitelja, a treba naglasiti kako su sve objave pisane na hrvatskom i engleskom jeziku kako bi se hrvatska povijest približila i stranoj publici. Zbog već više puta spomenute važnosti Senja za ranonovovjekovnu hrvatsku povijest, projekt je posvetio popriličan broj Facebook objava i senjskoj povijesti.

Prema analitičkim pomagalima Facebooka, najpopularnije objave o senjskoj povijesti su objave o Ivanu Lenkoviću, senjskom kaštelu i serijal od pet objava o topovima utvrde Nehaj. ${ }^{20}$ Objava Ivan Lenković - čovjek koji je oživio obranu Hrvatske podijeljena je i na mrežnoj stranici projekta zbog izrazite važnosti Lenkovića, kao senjskog kapetana, za organizaciju obrane Hrvatske, a

\footnotetext{
${ }^{20}$ Naravno, to nisu jedine objave o bogatoj senjskoj povijesti - posebno treba još napomenuti objavu Senj i utvrda Nehaj na prikazu Martina Stiera, oko 1660. godine, objavu Nikola Jurišić vojnik, diplomat i spasitelj Beča, serijal od četiri objave Izvještaji Ivana Lenkovića za utvrdu Senj iz 1550. godine, serijal od dvije objave o Izvještaju Ivana Lenkovića za utvrdu Senj iz 1563. godine te objava Izgled Uskoka u 16. stoljeću.
} 
tako i Senja, u 16. stoljeću. ${ }^{21}$ Stari senjski kaštel - oronuli dragulj grada objava je koja opisuje stari srednjovjekovni kaštel koji je nastao na najugroženijem uglu obrambenih zidina, a posebna pažnja posvećuje se i današnjem jako lošem stanju kaštela (urušen krov kule i oronuli zidovi). ${ }^{22}$ Serijal objava o topovima utvrde Nehaj prati povijesni put samih topova - od njihovog lijevanja u Senju, preko postavljanja u utvrdu, do konačnog premještanja topova na lafete prema obali kada se nakon prestanka osmanske opasnosti glavnina senjske obrane orijentirala prema Mletačkoj Republici. ${ }^{23}$ Recepcija objava o senjskoj povijesti bila je izuzetno pozitivna, a mnoge su objave potaknule i dodatna pitanja u komentarima, pa čak i manje diskusije o pojedinim temama. Posebno treba istaknuti kako su neke objave nagnale publiku da nadopuni znanja i konzultira stručnu literaturu što se lako može lako iščitati iz komentara.

Mrežna i Facebook stranica projekta Bulwark of Europe jasno pokazuju kako postoji prostor za popularizaciju senjske povijest te kako lokalna povijest, kontekstualizacijom u šire regionalne i europske okvire te iznošenjem zanimljivih epizoda, može postati intrigantan povijesni narativ - i to ne samo hrvatskoj već i međunarodnoj publici.

\section{Izazovi popularizacije povijesti}

Popularizacija povijesti podijelila je historiografiju - jedan dio povjesničara smatra kako ona otvara neslućene mogućnosti predstavljanja rezultata istraživanja, kao i kompleksnih povijesnih procesa i događaje široj publici, dok drugi smatraju kako je ona opasnost za klasičnu historiografiju koja počiva primarno na znanstvenoj produkciji. Treba li historiografija inzistirati samo na istraživanju povijesti u užim akademskim i znanstvenim krugovima ili treba izravno koristiti široj javnosti i više se usmjeriti prema njoj? Na navedeno pitanje ne postoji jednoznačan odgovor jer popularizacija povijesti ima svoje prednosti i nedostatke.

${ }^{21}$ Više o Ivanu Lenkoviću vidi u: A. M. GRÜENFELDER, 1996, 141-160; M. KRUHEK, 1995, 114-121.

${ }_{22}$ Tijekom povijesti kaštel je mijenjao svoju ulogu počevši od srednjovjekovnog kaštela, preko vojnog sjedišta, humanitarnog đačkog zavoda "Ožegovićianum" te raznih drugih sadržaja. Više o senjskom gradskom kaštelu vidi u: M. VILIČIĆ, 1988, 71-76.

${ }^{23}$ Zadnja objava u navedenoj seriji objava odnosi se i na današnju postavu topova u Gradu Senju upravo zbog svojevrsne popularizacije senjske uskočke povijesti i Vojne krajine - naravno, uz posebnu napomenu kako to nisu izvorni ranonovovjekovni topovi koji su bili dio nehajskog postava. Više o topovima utvrde Nehaj vidi u: Z. HERKOV, 1992, 35-46. 
Najveći nedostatak popularizacije upravo je velika mogućnost širenja netočnih informacija ili ideološki obojanih interpretacija te narativa objavama na društvenim mrežama i sličnim medijima. U znanstvenim historiografskim krugovima mogućnost objavljivanja radova čiji se narativ temelji na netočnim informacijama sveden je na minimum pomoću profesionalnog recenziranja rada prije njegovog objavljivanja. Širenje netočnih ili polutočnih informacija i interpretacija znatno je lakše u sferi popularizacije povijesti gdje proces profesionalnog historiografskog recenziranja jednostavno ne postoji. Međutim, može li se i kako izbjeći širenje netočnih informacija te ideološki obojanih pristupa prilikom popularizacije povijesti? Projekt Bulwark of Europe navedeni izazov popularizacije senjske povijesti rješava korištenjem stručne literature pri pisanju radova i objava za mrežnu i Facebook stranicu te preciznim citiranjem. Tako je, primjerice, sva stručna literatura korištena pri pisanju eseja o Senju i Nehaju navedena u prilogu rada. Ista praksa koristi se i za Facebook objave projekta gdje se uz svaku objavu navodi i izvor informacija, a uz to se pratitelje, koji u komentarima pokažu dodatni interes, usmjerava na relevantne historiografske radove kako bi se samostalno mogli bolje upoznati sa senjskom povijesti. Tako se mogućnost korištenja netočnih informacija svodi na minimum, a otvaranjem javne rasprave ispod članaka otvara se i mogućnost 'javnog recenziranja' napisanog te tako smanjuje mogućnost širenja krivih ili ideološki obojanih interpretacija o senjskoj povijesti.

S druge strane, popularizacija povijesti i digitalna humanistika otvaraju različite mogućnosti za povjesničare. Prije svega, historiografija može iskoristiti nove metode prezentacije rezultata historiografskih istraživanja - od kreativne vizualizacije statističkih podataka do izrade audio-vizualnih rekonstrukcija povijesne zbilje. Potencijal postoji i u domeni prezentacije muzejske građe, ali ništa manje bitna nije ni prezentacija na internetskim stranicama. Već je istaknut primjer 3D rekonstrukcija utvrde Nehaj i Senja na mrežnoj stranici projekta koje pružaju atraktivnu vizualizaciju povijesne zbilje zainteresiranoj publici. Drugi primjer vezan je uz historijsku geografiju, odnosno izradu povijesnih karata. Vizualizacija prostora, ali i fenomen AI procesa, oduvijek je pomagala pri tumačenju prošlosti, a svladavanjem modernih GIS (geografski informacijski sustav) tehnologijama vizualizacija postaje pristupačnija. Te vrste vizualizacije nisu korisne samo za širu javnost već i za samu akademsku historiografiju. Primjerice, izrada povijesnih karata na temelju različitih vojnih/poreznih popisa pograničnih društava pruža odličan uvid u proces formiranja Vojne krajine i njezine brojne funkcije. Povijesne karte izrađene u sklopu projekta Bulwark of Europe pružaju novi uvid i u senjsku ranonovovjekovnu povijest. 
Možemo zaključiti kako je pisanje o povijesti uvijek malo značilo bez čitatelja koji bi napisani tekst pročitao. Isto vrijedi i danas, samo što moderni "čitatelji" sve više postaju "slušatelji" ili "gledatelji". Popularizacija povijesti danas je gotovo neminovna, tj. ona se odvija i odvijat će se uz pomoć povjesničara ili bez nje. Neaktivnost povjesničara u popularizaciji može samo rezultirati marginalizacijom akademske historiografije u društvu. S druge strane, prednosti popularizacije povijesti svakako mogu koristiti znanosti i akademskoj historiografiji. Nadamo se da projekt Bulwark of Europe pruža pozitivan primjer popularizacije vojnokrajiške (a time i senjske) povijesti.

\section{Pristupačnost izvora i literature}

Jedna od temeljnih aktivnosti projekta usmjerena je prema digitalizaciji izvora i literature, tj. prikupljanju već ranije digitaliziranih podataka. Pristupačnost literature dijelom je ograničena autorskim pravima koja ograničavaju prenošenje najrecentnije literature. Projekti i baze podataka, kao primjerice Academia.edu ili Hrčak, u značajnoj mjeri anuliraju taj problem, no dio tekstova - primarno u tematskim zbornicima radova ili stranim periodikama "zaključanim" iza tzv. paywalla - i dalje ostaje nedostupan čitateljima. Takve tekstove nastojimo osobno pribaviti te njihove spoznaje u što je većoj mjeri prenijeti u našim objavama kako bismo čitatelje upoznali s recentnim historiografskim pomacima i istraživanjima.

S druge strane, izvori su nešto pristupačniji. ${ }^{24}$ Iako je objavljen tek vrlo mali dio izvora za vojnokrajišku povijest, oni izvori koji su objavljeni vrlo su korisni i još se uvijek nedovoljno koriste. Najveći dio izvora za hrvatski povijesni prostor - pa tako i za povijest ranonovovjekovnog Senja - izdan je tijekom 19. i 20. stoljeća. Gotovo sve veće zbirke izvora već su ranije digitalizirane aktivnostima raznih udruga, a na našoj stranici nalaze se poveznice na njih. ${ }^{25} \mathrm{Za} \mathrm{povijest} \mathrm{Senja,}$ kao važnog krajiškog središta, posebno su važan izvor izvješća Ivana Lenkovića. Sačuvana su nam dva - izvještaj iz 1550 . godine ${ }^{26}$, koji govori o izgradnji utvrde izvori/.

${ }^{24}$ Popis svih dostupnih izvora projekta vidi na: https://vojnakrajina.ffzg.unizg.hr/skenirani-

${ }^{25}$ Navodimo tek neke, za senjsku povijest najrelevantnije, kao što su: Habsburški spomenici Kraljevine Hrvatske, Dalmacije i Slavonije (https://dizbi.hazu.hr/a/?pr=i\&id=214363), Spomenici Hrvatske krajine (https://dizbi.hazu.hr/a/?pr=i\&id=214346) te niz kraćih izvora objavljenih u Vjes(t)niku Kr. hrvatsko-slavonsko-dalmatinskog zemljaskog arkiva (današnji Hrvatski državni arhiv u Zagrebu; https://library.hungaricana.hu/en/collection/croatian_state_archives_arhivski_ vjesnik/).

${ }^{26}$ Dostupno online na: https://vojnakrajina.ffzg.unizg.hr/utvrde-i-obrana-u-izvjestaju-ivanalenkovica-iz-1550-godine/. 


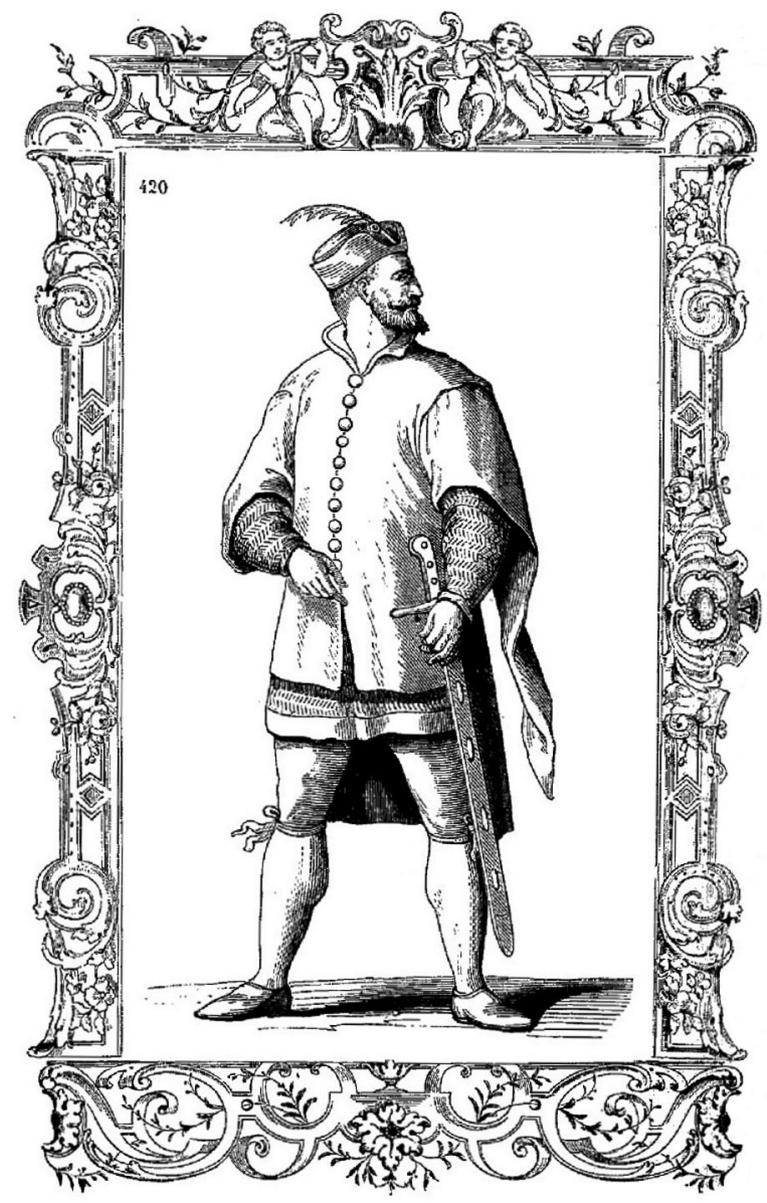

Sl. 5. Uskočki kapetan - Capo di Evscochi (izvor: C. VECELLIO, 1590, URL: https://gallica.bnf.fr/ark:/12148/btv1b8446755d)

Nehaj, te izvještaj iz 1563 . godine. ${ }^{27} \mathrm{Tu}$ je, dakako, i vrlo vrijedna zbirka izvora o senjskim uskocima (Monumenta historiam Uscocchorum illustrantia Mondo, hrv. Spomenici koji rasvjetljavaju povijest uskoka) koju je početkom 20. stoljeća sakupio i objavio Karlo Horvat. ${ }^{28}$

27 Dostupno online na: https://vojnakrajina.ffzg.unizg.hr/utvrde-i-obrana-u-izvjestaju-ilenkovica-iz-1563-godine/.

28 Dostupno online na: https://vojnakrajina.ffzg.unizg.hr/monumenta-historiamuscocchorum-illustrantia/. 
$\mathrm{Na}$ jedan izvor voljeli bismo skrenuti posebnu pažnju. Riječ je o djelu De gli Habiti Antichi e Modérni di Diversi Parti di Mondo (hrv. Antička i moderna odjeća različitih dijelova svijeta), koje je 1590. godine izdao talijanski umjetnik, slikar i tiskar Cesare Vecellio (o. 1521. - o. 1601). Vecellio je rođen i djelovao u Veneciji, a u svojem je djelu donio likovne prikaze i opise naroda različitih dijelova svijeta. Među više od 420 prikaza $^{29}$ nalazi se i osam prikaza ljudi hrvatskog povijesnog prostora, a za nas je posebno zanimljiv i jedan od najranijih prikaz i opisa senjskih uskoka, tj. konkretno uskočkog kapetana (tal. Capo di Evscochi)..$^{30}$ Prenosimo zanimljiv dio teksta: "Ova žestoka i strašna nacija podložna je austrijskom nadvojvodi Karlu. Žive u divljoj i planinskoj zemlji, borave u mjestu zvanom Senj, a žive samo od krađe ili pljačke. Žive u Dalmaciji, na granici s Turcima s kojima stalno ratuju. Neki od njihovih brodova su naoružani i s njima napadaju i pljačkaju velike brodove i druga plovila koja prevoze teret. Sve u svemu užasni su ljudi, koji žive na granici više nacija, hrabri su i veoma ratoborni. Njihovi vođe nose halje od lana ili svile raznih kvaliteta. U ratu tijelo pokrivaju finim mrežastim košuljama [lančani oklop; hrv. verižnjača]. Njihova odjeća, slična odjeći Slavena, duga je pozadi i kratka sprijeda. Njihovi rukavi spuštaju se do sredine ruke i izrađeni su od jednog komada tkanine. Nose kratka oružja - uglavnom koriste sablje, kao vrlo prikladno oružje za borbu na moru. Kaput, koji obično ne stežu remenom, zakopčan je zlatnim ili srebrnim gumbima. Pokrivaju glavu malom baršunastom kapom ili nekom drugom kapom neobična oblika; pošto je podijeljen sa strane spuštaju stražnji dio do sredine vrata, a prednji dio podižu. Toliko su spretni i okretni da se kreću preko svojih nepristupačnih planina brzinom divokoze. Nose crvene ili zelene hlače te izdržljive velike cipele."

\section{Zaključak}

Projekt Bulwark of Europe pokazuje da povjesničari ne bi trebali djelovati isključivo ex cathedra, već bi - kao što mnogi slučajevi pokazuju trebali "ući" u društvo, pokrenuti dijaloge i diskusije te prezentirati historiografske spoznaje zainteresiranoj publici na jednostavan i interaktivan način, služeći se svojim profesionalnim znanjem na opću korist. Dodatan izazov pritom predstavlja činjenica da zainteresiranu publiku više ne čine samo "čitatelji" već i "slušatelji" i "gledatelji" zbog čega je za povjesničare ključno koristiti resurse

\footnotetext{
${ }^{29}$ K. N. SIMONČIĆ, 2018, 56-57.
}

${ }^{30}$ Ovdje prenosimo samo prijevod opisa uskoka. Prijevod ostalih sedam prikaza bit će objavljen u: F. ŠIMUNJAK, 2021; Više o odjeći uskoka vidi u: M. GUŠIĆ, 1973, 9-120. 
suvremenog doba. Prije svega, riječ je o popularizaciji povijesti posredstvom društvenih mreža, ali isto tako i o otvaranju historiografije prema modernim tehnologijama, ponajviše u okviru tzv. digitalne humanistike, koja olakšava vizualnu prezentaciju prošle zbilje.

Iako je ranonovovjekovna senjska povijest dobro poznata među lokalnim stanovništvom, upravo je posredovanje povjesničara i društvenih mreža ključno za otvaranje i prezentiranje lokalne povijesti široj - bilo nacionalnoj ili međunarodnoj - publici. Takvi pristupi sa sobom nose određene izazove, no oni se profesionalnim historiografskim pristupom mogu svesti na minimum, čime prednosti pristupa nadmašuju nedostatke. Odaziv na primjere popularizacije senjske ranonovovjekovne povijesti pokazuje kako interes za zanimljive lokalne priče postoji i izvan okvira lokalne zajednice - bilo da je riječ o utvrdama, ljudima ili povijesnim događajima. Priče o važnijim povijesnim ličnostima kao što su Ivan Lenković ili senjski uskoci zaslužuju biti ispričane i izvan okvira lokalne zajednice ili pak uskih akademskih krugova, a upravo je na povjesničarima i popularizacijskim projektima kao što je Bulwark of Europe zadatak da te priče iz minulih stoljeća prezentiraju na inovativan i intrigantan način novim generacijama.

\section{Literatura}

\section{Knjige i članci}

János M. BAK - Béla K. KIRÁLY (ur.), From Hunyadi to Rákóczi: war and society in late medieval and early modern Hungary, Social Science Monographs - Brooklyn College Press - Columbia University Press, New York, 1982.

Catherine Wendy BRACEWELL, Senjski uskoci: piratstvo, razbojništvo i sveti rat na Jadranu u šesnaestom stoljeću, Barbat, Zagreb, 1997.

W. Guy CLARK - John K. LEE, The Promise of Digital History in the Teaching of Local History, The Clearing House, 78/2, 2004, 84-87.

Rebecca CONARD, Complicating Origin Stories: The Making of Public History into an Academic Field in the United States, u: David DEAN (ur.), A Companion to Public History, Wiley Blackwell, New York, 2018, 19-33.

David DEAN, Introduction, u: David DEAN (ur.), A Companion to Public History, Wiley Blackwell, New York, 2018, 1-13.

Anna Maria GRÜENFELDER, Senj i njegovi kapetani, Senjski zbornik, 23, Senj, 1996, 141-160.

Marija GUŠIĆ, Nošnja senjskih uskoka, Senjski zbornik, 5, Senj, 1973, 9-120. 
Petar HEGEDIĆ - Marta JURKOVIĆ - Nikola OSTOJČIĆ - Filip ŠIMUNJAK, Popis isplata vojsci u Hrvatskoj i Slavonskoj krajini u listopadu i studenome 1556, prema dvama registrima: prilog istraživanju rane faze vojnokrajiške povijesti, Radovi Zavoda za Hrvatsku povijest, 51/2, 2019, 345-375.

Zlatko HERKOV, Ljevaonica topova u Senju 1541., Senjski zbornik, 19, Senj, 1992, 35-46.

Željko HOLJEVAC - Nenad MOAČANIN, Hrvatsko-slavonska Vojna krajina i Hrvati pod vlašću Osmanskoga Carstva u ranome novom vijeku, Leykam International, Zagreb, 2007.

Zorislav HORVAT, Burgologija: Srednjovjekovni utvrdeni gradovi kontinentalne Hrvatske, UPI - 2M Plus, Zagreb, 2014.

Ivan JURKOVIĆ, Vojni ustroj i obrana Kraljevstva: Cito. Cito. Cito. Citissime!, u: Marija KARBIĆ (ur.), Vrijeme sazrijevanja, vrijeme razaranja Hrvatske zemlje u kasnome srednjem vijeku, Matica hrvatska, Zagreb, 2019, 115-135.

Marta JURKOVIĆ - Filip ŠIMUNJAK, Projekt Bulwark of Europe - digitalizacija habsburško-osmanske krajine, @rhivi, 8, 2020, 32-33.

Karl KASER, Slobodan seljak $i$ vojnik: povojačenje agrarnog društva u Hrvatskoslavonskoj Vojnoj krajini (1535. - 1881.), sv. 1, preveo Josip Brkić, Naprijed, Zagreb, 1997.

Hilda KEAN, Where Is Public History?, u: David DEAN (ur.), A Companion to Public History, Wiley Blackwell, New York, 2018, 33-45.

Vedran KLAUŽER, Ustrojstvo i djelovanje Senjske kapetanije od njezina osnutka do organizacije Vojne krajine po vrhovnom zapovjedniku Ivanu Lenkoviću (1469.1563.), Hrvatski studiji Sveučilišta u Zagrebu, Zagreb, 2015.

Ljudevit KRMPOTIĆ (ur.), Izvještaji o utvrđivanju granica hrvatskog kraljevstva od 16. do 18. stoljeća, Nakladni zavod Hrvatski zapisnik, Hannover - Karlobag Čakovec, 1997.

Milan KRUHEK, Krajiške utvrde i obrana Hrvatskog Kraljevstva tijekom 16. stoljeća, Institut za suvremenu povijest, Zagreb, 1995.

András KUBINYI, The Battle of Szávaszentdemeter-Nagyolaszi (1523). Ottoman Advance and Hungarian Defence on the Eve of Mohács, u: Géza DÁVID - Pál FODOR (ur.), Ottomans, Hungarians, and Habsburgs in Central Europe. The Military Confines in the Era of Ottoman Conquest, Brill, Leiden - Boston - Köln, 2000, 71-115.

Josip KURELIĆ, Austrija, u: Marija KARBIĆ (ur.), Vrijeme sazrijevanja, vrijeme razaranja Hrvatske zemlje u kasnome srednjem vijeku, Matica hrvatska, Zagreb, 2019, 545-561.

Sanja LAZANIN - Nataša ŠTEFANEC, Habsburg Military Conscription and Changing Realities of the Triplex Confinium, 16th-18th Centuries, u: Drago ROKSANDIĆ Nataša ŠTEFANEC (ur.), Constructing border societies on the Triplex Confinium, Central European University, Budapest, 2000, 91-116. 
Radoslav LOPAŠIĆ (ur.), Spomenici hrvatske krajine, sv. 3, Od godine 1693 do 1780 i u dodatku od godine 1531 do 1730, Academia scientarum et artium Slavorum meridionalium, Zagreb, 1889.

Fedor MOAČANIN, Vojna krajina do kantonskog uređenja 1787., u: Nataša ŠTEFANEC (ur.), Fedor Moačanin: Radovi iz povijesti Vojne krajine, Srpsko kulturno društvo Prosvjeta, Zagreb, 2017, 139-193.

Géza PÁLFFY, The Origins and Development of the Border Defence System against the Ottoman Empire in Hungary (Up to the Early Eighteenth Century), u: Géza DÁVID - Pál FODOR (ur.), Ottomans, Hungarians, and Habsburgs in Central Europe: The Military Confines in the Era of Ottoman Conquest, Brill, Leiden Boston - Köln, 2000, 3-69.

Karlo RUKAVINA, Utvrda Nehaj - povod gradnji i tipizacija, ProTempore, 16, 2021 (rad je prihvaćen za objavu u časopisu 28. 11. 2020.; radna verzija 17 stranica).

Katarina Nina SIMONČIĆ, Pitanje odjevnog identiteta Hrvata u ilustriranim knjigama odjevne tematike s kraja 16. stoljeća, u: Dragan DAMJANOVIĆ - Lovorka MAGAŠ BILANDŽIĆ (ur.), Imago, imaginatio, imaginabile - Zbornik u čast Zvonka Makovića, Filozofski fakultet Sveučilišta u Zagrebu, Filozofski fakultet u Zagrebu, Zagreb, 2018, 55-73.

Damir STANIĆ, Bihać kao sjedište Bihaćke kapetanije i slobodni kraljevski grad, Filozofski fakultet Sveučilišta u Zagrebu, Zagreb, 2020.

Ferenc SZAKÁLY, Phases of Turco-Hungarian Warfare before the Battle of Mohacs (1365-1526), Acta Orientalia Academiae Scientiarum Hungaricae, 33, 1979, 65-111.

Ferenc SZAKÁLY, The Hungarian-Croatian border defense system and its collapse, u: János M. BAK - Béla K. KIRÁLY, From Hunyadi to Rákóczi: war and society in late medieval and early modern Hungary, Social Science Monographs - Brooklyn College Press - Columbia University Press, New York, 1982, 141-158.

Filip ŠIMUNJAK, Opis ljudi i nošnji hrvatskog povijesnog prostora 1590. godine iz pera Cesare Vecellija (1521 - 1601), Essehist, 12, 2021 (rad je prihvaćen za objavu u časopisu 10. svibnja 2021., radna verzija 21 stranica).

Filip ŠIMUNJAK, Razvoj publike - Priručnik za edukaciju arhivista i baštinskih stručnjaka: "Bulwark of Europe - tehnologije i izvori", u: Vlatka LEMIĆ Tamara ŠTEFANAC (ur.), Razvoj publike: Priručnik za edukaciju arhivista $i$ baštinskih stručnjaka, ICARUS Hrvatska, Zagreb, 2021, 65-67.

Nataša ŠTEFANEC, Država ili ne: ustroj Vojne krajine 1578. godine i hrvatsko-slavonski staleži u regionalnoj obrani i politici, Srednja Europa, Zagreb, 2011.

Melita VILIČIĆ, Senjski kaštel - obnova i namjena, Senjski zbornik, 13, Senj, 1988, 71-76.

Andrej ŽMEGAČ, Kaštel Nehaj kraj Senja, Institut za povijest umjetnosti, 26, 2002, $19-29$.

Andrej ŽMEGAČ, Nekoliko starih prikaza Nehaja, Senjski zbornik, 23, Senj, 2004, 5-14. 


\section{Internetski izvori}

HABSBURŠKI KRAJIŠKI POPISI, URL: https://vojnakrajina.ffzg.unizg.hr/krajiskipopisi/ (2021-13-7)

HABSBURŠKI SPOMENICI KRALJEVINE HRVATSKE, DALMACIJE I SLAVONIJE, URL: https://dizbi.hazu.hr/a/?pr=i\&id=214363 (2021-13-7)

IZVORI, URL: https://vojnakrajina.ffzg.unizg.hr/skenirani-izvori/ (2021-14-6)

SPOMENICI HRVATSKE KRAJINE, URL: https://dizbi.hazu.hr/a/?pr=i\&id=214346 (2021-6-7)

UTVRDA NEHAJ, URL: https://vojnakrajina.ffzg.unizg.hr/nehaj-3/ (2021-28-6)

UTVRDE I OBRANA U IZVJEŠTAJU IVANA LENKOVIĆA IZ 1550. GODINE, URL: https://vojnakrajina.ffzg.unizg.hr/utvrde-i-obrana-u-izvjestaju-ivana-lenkovicaiz-1550-godine/(2021-15-6)

UTVRDE I OBRANA U IZVJEŠTAJU IVANA LENKOVIĆA IZ 1563. GODINE, URL: https://vojnakrajina.ffzg.unizg.hr/utvrde-i-obrana-u-izvjestaju-i-lenkovicaiz-1563-godine/(2021-15-6)

UTVRDE SENJA, URL: https://vojnakrajina.ffzg.unizg.hr/grad-senj/ (2021-28-6)

Cesare VECELLIO, De gli Habiti Antichi e Modérni di Diversi Parti di Mondo, Damian Zenaro, Venecija, 1590, URL: https://gallica.bnf.fr/ark:/12148/btv1b8446755d/ (2021-28-6)

VJES(T)NIK KR. HRVATSKO-SLAVONSKO-DALMATINSKOG ZEMLJASKOG ARKIVA, URL: https://library.hungaricana.hu/en/collection/croatian_state_ archives_arhivski_vjesnik/ (2021-30-6)

\section{THE CHALLENGES AND POSSIBILITIES OF THE POPULARISATION OF LOCAL HISTORY - THE EXAMPLE OF EARLY-MODERN MILITARY FRONTIER AND HISTORY OF SENJ}

\section{Summary}

In today's digital world, marked by globalisation and the rapid transfer of information over extraordinary distances, the social and public position of historiography - which has found itself in unprecedented new conditions - has been brought into question, particularly when it comes to the challenges of the popularisation of history. Within the series of questions that the popularisation of history raises, it is possible to separate a smaller part that interests us here - local history and its presentation. In this paper will be presented the challenges and possibilities of the popularisation of the scientifically-based knowledge of historiography using the example of Senj's history and the Bulwark of Europe project.

Keywords: public history, popularisation of history, Senj, Nehaj, Uskoks, Military Frontier 